\title{
Coping strategies among nursing staff at a university hospital
}

\author{
Estratégias de coping em trabalhadores de enfermagem de um hospital universitário
}

\author{
Estrategias de afrontamiento en trabajadores de enfermería de un hospital universitario
}

José Ricardo Ferreira da Fonseca ${ }^{1}$, Ana Lucia Siqueira Costa ${ }^{2}$, Diandra Sabrina Seixas Coutinho ${ }^{1}$, Raquel da Costa Gato $^{1}$

Objective: to evaluate the association of coping strategies and characteristics of nursing professionals at a university hospital. Methods: cross-sectional, quantitative study, with 92 professional nursing of an inpatient unit of a university hospital. To evaluate them, Problems Coping Scale Mode was used, and the analysis was through the Spearman correlation coefficient and the Mann-Whitney test. Results: a strategy focused on the problem was the most used, women seek more the strategy focused in religious practice than men $(p=0.017)$. The age $(p=0.031)$, individual income $(p=0.049)$ and working hours $(p=0.027)$ had also significantly correlation with the dimensions of the scale. Conclusion: socio-demographic characteristics are associated with coping strategies and may influence the choice of the individual for coping strategy.

Descriptors: Occupational Health; Mental Health; Nursing; Adaptation, Psychological.

Objetivo: avaliar a associação das estratégias de coping e as características dos profissionais de enfermagem de um hospital universitário. Métodos: pesquisa transversal, quantitativa, com 92 profissionais de enfermagem de unidade de internação de um hospital universitário. Para avaliação utilizou a Escala de Modo de Enfrentamento de Problemas, e para análise empregou o coeficiente de correlação de Spearman e o teste Mann-Whitney. Resultados: a estratégia focada no problema foi a mais utilizada, as mulheres buscam mais a estratégia focada na prática religiosa que os homens $(p=0,017)$; a idade $(p=0,031)$, renda individual $(p=0,049)$ e carga horária de trabalho $(p=0,027)$ também tiveram correlação significativa com as dimensões da escala. Conclusão: as características sociodemográficas tem associação com as estratégias de coping e podem influenciar a escolha do indivíduo pela estratégia de enfrentamento.

Descritores: Saúde do Trabalhador; Saúde Mental; Enfermagem; Adaptação Psicológica.

Objetivo: evaluar la asociación de estrategias de afrontamiento y características de los profesionales de enfermería de un hospital universitario. Métodos: estudio transversal, cuantitativo, con 92 profesionales de enfermería de unidad de hospitalización de un hospital universitario. Para evaluar, se utilizó la Escala de Modo de Afrontamiento de Problemas, y para análisis se utilizó el coeficiente de correlación de Spearman y el test de Mann-Whitney. Resultados: la estrategia centrada en el problema fue la más utilizada, las mujeres buscan más la estrategia centrada en la práctica religiosa que los hombres $(\mathrm{p}=0,017)$; la edad $(\mathrm{p}=0,031)$, la renta individual $(\mathrm{p}=0,049)$ y carga de trabajo $(\mathrm{p}=0.027)$ también se correlacionaron significativamente con las dimensiones de la escala. Conclusión: características sociodemográficas se asocian con las estrategias de afrontamiento y pueden influir en la elección del individuo por la estrategia de afrontamiento.

Descriptores: Salud Laboral; Salud Mental; Enfermería; Adaptación Psicológica.

\footnotetext{
${ }^{1}$ Universidade Federal do Amazonas. Manaus, AM, Brazil

${ }^{2}$ Universidade de São Paulo, Escola de Enfermagem. São Paulo, SP, Brazil

Corresponding author: José Ricardo Ferreira da Fonseca

Escola de Enfermagem de Manaus, Rua Terezina, 495, Adrianópolis, CEP: 69057-070. Manaus, AM, Brazil. E-mail: jrffonseca@usp.br
} 


\section{Introduction}

Nursing professionals are vulnerable to stress at work due to significant working hours for patient's care and contact with family members. These activities require a close relationship with people and work environment, requiring effective coping strategies that can vary according to the personality or experiences of the individual, as well as the characteristics of the situation $^{(1)}$.

Coping strategies are cognitive and behavioral efforts to reduce existing demands, determined by the way the individual uses the strategies for internal and external resources such as health, beliefs, responsibility, support, social skills and materials, and basic resources to decrease stress levels ${ }^{(2)}$.

The impact of problems to be faced by nursing professionals can be checked in family, social, academic and occupational contexts. It directly interferes the quality of life, job satisfaction and physical and emotional well-being ${ }^{(3)}$.

Occupational nursing activity in all health care sectors is considered exhausting due to the working hours and its own characteristics as a result of lack of labor relationships and dissatisfaction with low wages and promotions. Such situations influence the care provided to patients ${ }^{(4)}$. Thus, occupational stress has required constant coping strategies of nursing professionals triggering a mental suffering, which represent the main causes of absenteeism ${ }^{(5)}$.

The high demand and increased psychological demands, can also reduce the work capacity of nursing professionals $\mathrm{s}^{(6)}$. Thus, it is seen the need to develop studies to know the coping strategies for stress in the workplace, to propose improving the quality of life of workers, and to reflect on nursing care and minimizing risks from the occupational stress, reducing professional absenteeism.

Based on the above, the following questions were formulated: What are the coping strategies most used by professionals to face the stress? Is there an association of coping strategies with the socio-demographic characteristics? Thus, the study aimed to evaluate the association of coping strategies and socio-demographic characteristics of nursing professionals at a university hospital.

\section{Method}

It is a transversal, quantitative research, with nursing professionals of a university hospital in the city of Manaus, Amazonas, North Region of Brazil. The institution has 392 nursing professionals, distributed in 10 units of different complexities of care and health specialties.

Of the total of 122 professionals in the four-unit nursing team (hospitalization: medical clinic, surgical, orthopedic and neurology), there were 92 people included who agreed to participate, $30(32.6 \%)$ the medical clinic, 29 (315\%) of the surgical clinic, $n=13$ (14.1\%) of neurology clinic and $20(21.7 \%)$ of the orthopedic clinic.

For data collection, an instrument consisted of different variables was used: age; gender; working time in the unit; work shift; hours working per week; time training; work sector; professional category and type of employment relationship and link work with another institution.

The coping was conducted using the Problem Coping Scale $\operatorname{Mode}^{(7)}$, translated and validated to Portuguese with factor analysis considered reliable (Cronbach's alpha from 0.70 to 0.84 in its dimensions) (7). This instrument has 45 items and identifies four ways of coping: 1 . Coping strategies focused on the problem, with eighteen items covering approach behaviors in relation to the stressor, performed by the individual in order to solve the problem. They also include items involving highly cognitive active efforts aimed at re-evaluation of the problem, realizing it in a positive way; 2. Coping strategies based on 
emotion, composed of fifteen items including negative emotional reactions such as anger or tension, fancy or unrealistic thinking facing the magic solution to the problem, avoidance response and blaming reaction from someone else or himself ${ }^{(7)}$. There are cognitive and behavioral strategies that can fulfill palliative role in addressing and or result in the removal of the stressor; 3. Religious practice/fancy thinking, consisting of seven items with thoughts and religious behaviors that can assist in solving the problem, fancy thoughts permeated by feelings of hope and faith; 4. Seeking social support, with five items representing the demand for instrumental, emotional or information support. The scale is measured in five Likert points from 01 to 05 . The closer to 5 the better the strategies used ${ }^{(7)}$.

Professionals who agreed to participate and work for more than six months at the institution and were present in the units were included. Thus, professionals who were removed from service, on vacation or on sick leave in the data collection period did not participate.

Data collection was from April to May 2014, by previously trained people. The interview schedule was established with the professional, without interfering in the assistance and carried out in a reserved place, ensuring participant privacy. The collection of data was performed in two stages. The first one, consisted of face to face interview to collect socio-demographic data. The second part was fulfilling the Problem Coping Scale Mode. After each interview, the forms were placed in sealed envelopes, ensuring data confidentiality.

Analysis was performed using the Statistical Package for the Social Sciences version 21.0. Descriptive statistics were made with frequency, percentage, average, median, and standard deviation. The Spearman correlation coefficient test and the Mann-Whitney test were used to check the association between socio-demographic variables and the four dimensions of Problem Coping Mode Scale, considering a confidence interval of $95 \%$ and level significance of $5 \%$. The scale obtained a Cronbach alpha of 0.84 , with good internal consistency.

The research had minimum risks by recalling stressful situations. The benefits were indirectly by stimulating intervention strategies for enhancement of professional coping. The research was approved by the Ethics Committee in Research under number 15582213.6.0000.5020.

\section{Results}

Of the participants, there was a predominance of women (81.5\%), and nursing technicians as occupation (63.0\%). The medical and surgical clinics concentrated the largest number of professionals with $32.6 \%$ and $31.5 \%$ respectively. Most of the participants (43.5\%) worked in night shifts, $85.9 \%$ were statutory employees. However, $64.1 \%$ had up to two working places (Table 1).

Table 1 - Socio-demographic characteristics of the 92 nursing professionals

\begin{tabular}{|c|c|}
\hline Variables & $n(\%)$ \\
\hline \multicolumn{2}{|l|}{ Gender } \\
\hline Male & $17(18.5)$ \\
\hline Female & $75(81.5)$ \\
\hline \multicolumn{2}{|l|}{ Professional Category } \\
\hline Nurse & $16(17.4)$ \\
\hline Nursing Technician & $58(63.0)$ \\
\hline Nursing Assistant & $18(19.6)$ \\
\hline \multicolumn{2}{|l|}{ Work Sector } \\
\hline Medical clinic & $30(32.6)$ \\
\hline Surgical clinic & $29(31.5)$ \\
\hline Neurology clinic & $13(14.1)$ \\
\hline Orthopedic clinic & $20(21.7)$ \\
\hline \multicolumn{2}{|l|}{ Work shift } \\
\hline Morning ( 7 am to $1 \mathrm{pm}$ ) & $9(9.8)$ \\
\hline Afternoon ( $1 \mathrm{pm}$ to $7 \mathrm{pm}$ ) & $10(10.9)$ \\
\hline Night (7 pm to $7 \mathrm{am})$ & $40(43.5)$ \\
\hline Daytime ( 7 am to $7 \mathrm{pm}$ ) & $31(33.7)$ \\
\hline Night and daytime* & $2(2.2)$ \\
\hline \multicolumn{2}{|l|}{ Other work type } \\
\hline Without other job & $28(30.4)$ \\
\hline Up to two jobs & $59(64.1)$ \\
\hline Up to three jobs & $5(5.4)$ \\
\hline
\end{tabular}


The average age of professionals was 43 years old, the median individual income was five times the minimum wage. They had on average two children. The average time since graduation was 17.12 years and 13.46 years of work in the institution. There was an average of 31.60 hours per week, with a total working hours of all the work contracts of 53.29 hours on average (Table 2).

As the average in the scores of problem coping scale mode, the coping focused on the problem was the most commonly strategy used by nurses (3.86) followed by the searching for religious practice/ fancy thinking (3.46) and searching for social support (3.28) and the strategy focused on emotion was the least used (2.53).

Distribution of problems coping strategies, women used more coping strategies than men. Searching for religious practices and fancy thinking showed that women seek more such strategies than men (Table 3).

As shown in Table 4, there was obtained positive and significant correlation between age and coping focused on the problem $(\mathrm{p}=0.031)$.

Table 2 - Distribution of average, median and standard deviation of the socio-demographic characteristics of the 92 nursing

\begin{tabular}{|c|c|c|c|}
\hline Variables & Average & Median & Standard deviation \\
\hline Age (Years old) & 43.08 & 41.00 & 9.405 \\
\hline Individual income (Minimum wage) & 5.46 & 5.00 & 2.984 \\
\hline Family income (Minimum wage) & 8.66 & 7.00 & 5.675 \\
\hline Number of children & 1.76 & 2.00 & 1.329 \\
\hline Time of graduation (years) & 17.12 & 14.00 & 8.101 \\
\hline Time working at the hospital (Years) & 13.46 & 11.00 & 7.972 \\
\hline Working hours per week (Hours) & 31.60 & 30.00 & 3.505 \\
\hline Total working hours of all their Jobs (Hours) & 53.29 & 60.00 & 16.531 \\
\hline
\end{tabular}

Table 3 - Average distribution of the scale dimensions scores according to coping strategies and gender

\begin{tabular}{|c|c|c|c|c|c|c|}
\hline Scale mode dimensions of problem coping & Gender & $\mathbf{n}$ & Average & Median & $\begin{array}{l}\text { Standard } \\
\text { deviation }\end{array}$ & Mann-whitney \\
\hline \multirow{2}{*}{ Coping faced on the problem } & Male & 17 & 3.717 & 3.890 & .6152 & \multirow{2}{*}{0.297} \\
\hline & Female & 75 & 3.895 & 3.890 & .5087 & \\
\hline \multirow{2}{*}{ Strategy focused on emotion } & Male & 17 & 2.453 & 2.670 & .6282 & \multirow{2}{*}{0.763} \\
\hline & Female & 75 & 2.557 & 2.530 & .5541 & \\
\hline \multirow{2}{*}{ Searching for religious practice/fancy thinking } & Male & 17 & 3.109 & 3.000 & 6379 & \multirow{2}{*}{$0.017^{*}$} \\
\hline & Female & 75 & 3.542 & 3.570 & .6272 & \\
\hline \multirow{2}{*}{ Searching for social support } & Male & 17 & 3.015 & 3.250 & .9979 & \multirow{2}{*}{0.256} \\
\hline & Female & 75 & 3.348 & 3.500 & .9323 & \\
\hline
\end{tabular}

*significance level $<0,05$ 
Table 4 - Correlation of socio-demographic characteristics and the dimensions of the scale mode of coping problems

\begin{tabular}{|c|c|c|c|c|c|}
\hline \multirow[b]{2}{*}{ Variables } & \multirow[b]{2}{*}{$P$ value } & \multicolumn{4}{|c|}{ Average of scores } \\
\hline & & $\begin{array}{l}\text { Coping focused } \\
\text { on the problem }\end{array}$ & $\begin{array}{l}\text { Strategy focused } \\
\text { on the emotion }\end{array}$ & $\begin{array}{c}\text { Searching for reli- } \\
\text { gious practice/fancy } \\
\text { thinking }\end{array}$ & $\begin{array}{l}\text { Coping focused } \\
\text { on the problem }\end{array}$ \\
\hline \multirow{2}{*}{ Age $(n=92)$} & Coefficient & $.226^{*}$ & -.087 & .113 & -.026 \\
\hline & $P$ value & .031 & .407 & .285 & .807 \\
\hline \multirow{2}{*}{ Individual income $(\mathrm{n}=90)$} & Coefficient & -.040 & .094 & -.157 & $-.208^{*}$ \\
\hline & $P$ value & .707 & .376 & .140 & .049 \\
\hline \multirow{2}{*}{ Total working hours of all their jobs $(n=92)$} & Coefficient & .046 & $.234^{*}$ & .203 & -.150 \\
\hline & $P$ value & .668 & .027 & .056 & .157 \\
\hline
\end{tabular}

As for individual income, there is a negative and significant correlation observed $(p=0.049)$ in the strategies searching for social support. Those who have lower individual income seek more social support than those with higher individual income.

For total working hours in all working places, there was a positive and significant correlation observed ( $p=0.027)$. This means that the higher the working hours, the more strategies focused on emotion are used. There were no significant correlations between family income, number of children, professional category, time since graduation, working sector, working time in the hospital, working hours per week and work shift to the dimensions of the scale.

\section{Discussion}

The study showed a predominance of female nurses, similar to other studies of the same population ${ }^{(2,8)}$. Nursing is a profession historically constituted mostly by women, because the idea of caring, protecting, was always present in a woman's life. However, the increasing of men in the profession is gradual $^{(9)}$. The population of nursing technicians is predominantly higher than nurses because they represent the majority of the workforce in patient care.

It is observed that despite the higher percentage of professionals acting in night shifts, there are still a part of the professionals who work only in the morning or the afternoon, concentrating the largest number of workers on day shift and not in night shifts.

The age of about 40 years old corresponds to the expected profile, similar to findings from another study with nursing professionals ${ }^{(2)}$. However, this data differs from another study with 68 nursing professionals from an adult intensive care unit of Porto Alegre Hospital where the average was 27 years old ${ }^{(8)}$, showing that the subjects of this study are experienced professionals.

Individual income compared to family income is one of the main family income. Thus, it is highlighted the important social role of the women, most of them in this study, to ensure their place in the labor market and maintenance of their family ${ }^{(9)}$.

This analysis can be reinforced by the long time since graduation, working in the unit, and the working 
hours faced, as well as double shifts faced by women in their homes and with their families. Women has gained their space in working area ${ }^{(10)}$.

The coping focused on the problem was the most used by the nurses in this study, similar to another Brazilian study, where coping strategies linked to emotional state influence promoting health and better quality of life in the workplace and in personal life ${ }^{(11)}$.

Study with nursing professionals of a private hospital in Southern Brazil, identified that the professionals used especially the strategies focused on emotion, on the problem and social support for coping the wear resulting from work ${ }^{(12)}$.

Intensive care unit nurses and intensive cardiac unit of a public hospital in Rio Grande do Sul, use coping strategies focused on solving problems in the workplace, and use the strategies focused on emotion with less frequency ${ }^{(13)}$.

Thus, it is observed that the agreement and disagreement presented in the literature regarding coping strategies identified in this study lead to the understanding that the choice of strategy depends on the occupational environment.

The assessment that the professional does for the stressor is decisive for the choice of coping strategies to be used in experienced wear, because if the strategy is effective, there can be solution of the problem and overcome the stressor. However, due to the ineffectiveness of the strategy, they continue the stress process, requiring reassessment of the stressor $^{(13)}$.

The searching for religious practice and fancy thinking was the coping strategy most used by women. In religious practice, the fact is that a belief is a positive factor in helping women coping better with the experienced situation. This positive influence of religion strengthens the individual, so they are able to deal more effectively with their conditions and their quality of life. Religion helps the development of a protective behavior, promoting a lifestyle and a healthier mental health ${ }^{(14)}$.

Regarding the younger health professionals, older health professionals mainly use coping strategy focused on the problem. These professionals have been working for an extended period in hospital and has a long time since graduation, giving them an important experience in the profession. The professional skill and experience over time are important to reduce the negative factors at work $^{(2)}$.

Professionals with lower individual income seek more strategies focused on social support. This searching for social support can have a meaning also of financial support from the family. In the literature, it is clear that social support is a protection strategy and represents the material and psychological resources available for the individual, received from their social network (family, friends, co-workers) to face the problems in daily life ${ }^{(15)}$.

Strategies focused on emotion are most used by professionals who have higher working hours. The increased working hours is a constant search for multiple tasks, financial stability, which may lead the nursing professional to illness by excessive activities and workload ${ }^{(16)}$. This fact triggers a physical and emotional stress, which may explain the search for coping strategies, especially those focused on emotion.

A study with Nurses in Florida State in the United States, adds that the greater the perception of experienced stress, the greater the search for coping strategies and adopt positive attitudes for wear ${ }^{(17)}$. Similarly, a study of Finnish nurses found that professionals who have high workload have better development of coping strategies ${ }^{(18)}$. Therefore, increasing workload and wear experienced at work, require professional resources and coping strategies to minimize stress suffered at work. 
The focus of coping strategies are different, changing according to the nurse's characteristics and situations experienced at work. Thus, it is understood that the choice of strategy depends not only on the work environment, but individual characteristics of professionals.

\section{Conclusion}

The coping strategy more used was focused on the problem. Women used more the strategy of searching of religious practice than men.

In this study, socio-demographic characteristics such as age, individual income and workload were associated, respectively, with the strategies focused on coping the problem, searching for social support and focused on emotion. In this way, they influenced the choice by coping strategies.

Older people with lower income and higher working hours adopted different coping strategies. It is therefore crucial to consider the work environment and nurse's characteristics to know and understand what coping strategies can be stimulated and empowered for professional nursing forward to working wear.

\section{Collaborations}

Fonseca JRF collaborated in project elaboration or analysis and interpretation of data, article writing or critically review for important intellectual content and final approval of the version to be published. Costa ALS contributed in writing the article and critically review for intellectual content and final approval of the version to be published. Coutinho DSS and Gato RC contributed in the project elaboration, data collection, analysis and interpretation.

\section{References}

1. Teixeira CAB, Reisdorfer E, Gherardi-Donato ECS. Occupational stress and coping: reflection on the concepts and practice of hospital nursing. Rev Enferm UFPE on line. 2014 [cited 2015 Mar 28]; 8(supl. 1):2528-32. Available from: http://www. revista.ufpe.br/revistaenfermagem/index.php/ revista/article/view/6279/pdf_5765.

2. Guido LA, Linch GFC, Pitthan LO, Umann J. Stress, coping and health conditions of hospital nurses. Rev Esc Enferm USP. 2011; 45(6):1434-9.

3. Farias SMC, Teixeira OLC, Moreira W, Oliveira MAF, Pereira MO. Characterization of the physical symptoms of stress in the emergency health care team. Rev Esc Enferm USP. 2011; 45(3):722-9.

4. Alves PC, Neves VF, Coleta MFD, Oliveira AF. Evaluation of well-being at work among nursing professionals at a University Hospital. Rev LatinoAm Enfermagem. 2012; 20(4):701-9.

5. Mininel VA, Felli VEA, Silva EJ, Torri Z, Abreu AP, Branco MTA. Workloads, strain processes and sickness absenteeism in nursing. Rev Latino-Am Enfermagem. 2013; 21(6):1290-7.

6. Prochnow A, Magnago TSBS, Urbanetto JS, Beck CLC, Lima SBS, Greco PBT. Work ability in nursing: relationship with psychological demands and control over the work. Rev Latino-Am Enfermagem. 2013; 21(6):1298-305.

7. Seidl EMF, Tróccoli BT, Zannon CMLC. Análise fatorial de uma medida de estratégias de enfrentamento. Psic Teor Pesq. 2001; 17(3):22534.

8. Colossi EG, Calesso-Moreira M, Pizzinato A. Estratégias de enfrentamento utilizadas pela equipe de enfermagem de um CTI adulto perante situações de estresse. Rev Ciênc Saúde. 2011; 4(1):14-21.

9. Souza LL, Araújo DB, Silva DS, Bêrredo VCM. Representações de gênero na prática de enfermagem na perspectiva de estudantes. Ciênc Cogniç. 2014; 19(2):218-32. 
10. Costa LHR, Coelho EAC. Ideologies of gender and sexuality: the interface between family upbringing and nursing education. Texto Contexto Enferm. 2013; 22(2):485-92.

11. Martins JT, Bobroff MCC, Ribeiro RP, Costa VML, Cardelli AAM, Garanhani ML. Estratégias de enfrentamento às cargas de trabalho de enfermeiros de unidade de emergência. Rev Eletr Saúde Mental Álcool Drogas On line. [Internet]. 2012 [citado 2015 mar 28]; 8(3):14854. Disponível em: http://dx.doi.org/10.11606/ issn.1806-6976.v8i3p148-154

12. Benetti ERR, Stumm EMF, Weiller TH, Batista KM. Coping strategies and characteristics of the nursing staff of a private hospital. Rev Rene. 2015; 16(1):3-10.

13. Kleinubing RE, Goulart CT, Silva RM, Umann J, Guido LA. Estresse e coping em enfermeiros de terapia intensiva adulto e cardiológica. Rev Enferm UFSM. 2013; 3(2):335-44.
14. Murakami R, Campos CJG. Religião e saúde mental: desafio de integrar a religiosidade ao cuidado com o paciente. Rev Bras Enferm. 2012; 65(2):361-7.

15. Gomes RK, Oliveira VB. Depressão, ansiedade e suporte social em profissionais de enfermagem. Bol Psicol. 2013; 63(138):23-33.

16. Ribeiro RP, Martins JT, Marziale MHP, Robazzi MLCC. Work-related illness in nursing: an integrative review. Rev Esc Enferm USP. 2012; 46(2):495-504.

17. Wakim N. Occupational stressors, stress perception levels, and coping styles of medical surgical RNs: a generational perspective. J Nurs Adm. 2014; 44 (12):632-9.

18. Haybatollahi M, Gyekye SA. The moderating effects of locus of control and job level on the relationship between workload and coping behavior among finnish nurses. J Nurs Manag. 2014; 22(6):811-21. 